\title{
Stable $\mathrm{Ca}$ and $\mathrm{Sr}$ isotopes support volcanically-triggered
}

\section{biocalcification crisis during Oceanic Anoxic Event 1a}

\author{
Jiuyuan Wang, Andrew D. Jacobson, Bradley B. Sageman, Matthew T. Hurtgen \\ Department of Earth and Planetary Sciences, Northwestern University, Evanston, IL, USA, \\ 60208
}

Email address:jwang@earth.northwestern.edu

\section{SUPPLEMENTARY MATERIALS}

\section{Lithology}

Analytical Methods

$\delta^{13} \mathrm{C}$ Segmentation and Stratigraphic Correlation

Supporting Elemental and Isotopic Results

Sr Isotope Equilibration Sensitivity Analysis

\section{Figures}

Figure S1 - Stratigraphic height vs. $\mathrm{CaCO}_{3}$ abundance, $\mathrm{Mg} / \mathrm{Ca}, \mathrm{Sr} / \mathrm{Ca}, \mathrm{Mn} / \mathrm{Sr}$, and $\delta^{18} \mathrm{O}$ in bulk carbonate samples from ODP Hole 866A

Figure S2 - Cross-plots of isotopic data

Figure S3 - Cross-plots of isotopic and elemental ratios

Figure S4 - Comparison of $\delta^{44 / 40} \mathrm{Ca}$ data for Hole 866A reported here and elsewhere

Figure S5 $-{ }^{87} \mathrm{Sr} /{ }^{86} \mathrm{Sr}$ records of porewater and bulk carbonate from ODP Hole 866A

Figure S6 - Sensitivity analysis for Sr isotope equilibration between recrystallizing carbonate sediments and seawater

Figure S7 - Stratigraphic correlation of various geochemical proxy data for the entire study interval

\section{Tables}

Table S1 - Elemental and isotopic data presented in this study

Table S2 - Statistical data for linear regressions provided in Fig. 2

\section{Lithology}


Samples analyzed in this study are from Hole 866A drilled on the flanks of Resolution Guyot in the Mid-Pacific $\left(21^{\circ} \mathrm{N}, 174^{\circ} \mathrm{E}\right)$. Cyclic packstone-wackestones and oolitic/peloidal grainstones dominate the lithology, with lesser amounts of dolomitic packstone (Sager et al.,1993; Jenkyns and Strasser, 1995). Skeletal fragments of rudists, gastropods, and corals occur as sand-sized or larger grains (Sliter, 1995; Swinburne et al., 1995). Petrologic and elemental analyses reveal calcite as the primary mineralogy (Jenkyns and Strasser, 1995), although parts of the core below the study interval (>1200 mbsf) show evidence for dolomitization (Flood and Chivas, 1995).

Thermal gradients have convected large volumes of seawater through the carbonates (Paull et al., 1995). This mechanism may have supplied Mg necessary for dolomitization lower in the section (Food and Chivas, 1995), but the results presented here for the overlying limestone do not reveal significant secondary incorporation of seawater Ca and Sr. Limestone at the base of Hole 865, drilled on Allison Guyot, shows evidence for radiogenic Sr isotope equilibration with basaltic basement rocks (Paull et al., 1995). However, the Hole 866 rocks analyzed here, as well

as stratigraphically equivalent rocks at Hole 865 , display ${ }^{87} \mathrm{Sr} /{ }^{86} \mathrm{Sr}$ ratios consistent with the global record, and no evidence exists for alteration by younger fluids (Paull et al., 1995). While researchers have raised concerns about meteoric water diagenesis at Hole 866A (Röhl and Strasser, 1995), other studies suggest minimal alteration, or at least negligible impact on bulk sediment $\delta^{13} \mathrm{C}$ values and ${ }^{87} \mathrm{Sr} /{ }^{86} \mathrm{Sr}$ ratios (Jenkyns and Wilson, 1999).

\section{Analytical Methods}

We analyzed a subset of samples previously investigated by Mills et al. (2017). Rocks were powdered in a shatterbox equipped with an alumina ceramic grinding container. Approximately $\sim 200 \mathrm{mg}$ of powder was dissolved in $10 \mathrm{~mL}$ of ultrapure $5 \% \mathrm{HNO}_{3}$ in acid- 
cleaned centrifuge tubes for $12 \mathrm{hrs}$. The mixtures were centrifuged, and the supernatants were passed through $0.45 \mu \mathrm{m}$ polypropylene syringe filters, collected in Teflon beakers, dried at $90{ }^{\circ} \mathrm{C}$, and re-dissolved in $15 \mathrm{~mL}$ of $5 \% \mathrm{HNO}_{3}$ for elemental and isotopic analyses.

Subsamples of the solutions taken for elemental analysis were diluted to minimize matrix effects. Concentrations of $\mathrm{Ca}, \mathrm{K}, \mathrm{Mg}, \mathrm{Na}, \mathrm{Mn}$, and $\mathrm{Sr}$ were measured using a Thermo Scientific iCAP 6500 ICP-OES. K was not detected in the samples. Repeated analyses of NIST-1643f yielded results within $\pm 5 \%$ of reported concentrations. In addition, $\mathrm{Ca}$ and $\mathrm{Sr}$ concentrations measured by ICP-OES were within $\pm 5 \%$ of those determined by isotope dilution, as part of the double-spike methodologies presented below. Calcium concentrations were used to estimate the abundance of calcium carbonate (wt\%), assuming stoichiometric $\mathrm{CaCO}_{3}$.

Carbon and oxygen isotope ratios were measured using a Gas Bench connected to a Delta V Plus Isotope Ratio Mass Spectrometer (IRMS). Powders were purged with He for 7 minutes and then reacted overnight at $30{ }^{\circ} \mathrm{C}$ with $103 \%$ anhydrous $\mathrm{H}_{3} \mathrm{PO}_{4}$. Results were calibrated against NBS-18, NBS-19, and one internal $\mathrm{CaCO}_{3}$ standard. Data are reported in $\delta$-notation $\left(\delta^{13} \mathrm{C}\right.$ and $\delta^{18} \mathrm{O}$ ) relative to Vienna Peedee Belemnite (VPDB). The uncertainties $\left(2 \sigma_{\mathrm{SD}}\right)$ for $\delta^{13} \mathrm{C}$ and $\delta^{18} \mathrm{O}$ are $\pm 0.12 \%$ and $\pm 0.30 \%$, respectively.

Calcium and strontium isotope ratios were measured using a Thermo-Scientific Triton Thermal Ionization Mass Spectrometer (TIMS) equipped with $10^{11} \Omega$ amplifier resistors. Wang et al. (2019) recently reviewed the methods. In brief, a ${ }^{43} \mathrm{Ca}-{ }^{42} \mathrm{Ca}$ double-spike technique was used to measure ${ }^{44} \mathrm{Ca} /{ }^{40} \mathrm{Ca}$ ratios (Lehn et al., 2013). Procedural blanks quantified with an ${ }^{42} \mathrm{Ca}$ isotope dilution method were negligible $(\sim 50 \mathrm{ng}, \mathrm{n}=6)$ compared to the amount of sample $\mathrm{Ca}$ that was spiked and processed through column chemistry $(50 \mu \mathrm{g})$. Radiogenic and stable $\mathrm{Sr}$ isotope ratios $\left({ }^{87} \mathrm{Sr} /{ }^{86} \mathrm{Sr}\right.$ and ${ }^{88} \mathrm{Sr} /{ }^{86} \mathrm{Sr}$ ) were measured following Andrews et al. (2016) and 
Andrews and Jacobson (2017). ${ }^{87} \mathrm{Sr} /{ }^{86} \mathrm{Sr}$ ratios were measured using multi-dynamic mode, and instrumental mass fractionation was corrected by normalizing ${ }^{88} \mathrm{Sr} /{ }^{86} \mathrm{Sr}$ ratios to a value of 8.3752 using an exponential law. An ${ }^{87} \mathrm{Sr}^{84} \mathrm{Sr}$ double-spike technique was used to measure fractionated ${ }^{88} \mathrm{Sr} /{ }^{86} \mathrm{Sr}$ ratios. The ${ }^{88} \mathrm{Sr} /{ }^{86} \mathrm{Sr}$ data reduction includes input of corresponding ${ }^{87} \mathrm{Sr} /{ }^{86} \mathrm{Sr}$ ratios. Procedural blanks determined with an ${ }^{84} \mathrm{Sr}$ isotope dilution method were negligible ( $70 \mathrm{pg}, \mathrm{n}=3)$ compared to the amounts of $\mathrm{Sr}$ employed for both analyses (150 ng for ${ }^{87} \mathrm{Sr} /{ }^{86} \mathrm{Sr}$ and $200 \mathrm{ng}$ for $\left.{ }^{88} \mathrm{Sr} /{ }^{86} \mathrm{Sr}\right) \cdot{ }^{44} \mathrm{Ca} /{ }^{40} \mathrm{Ca}$ and ${ }^{88} \mathrm{Sr} /{ }^{86} \mathrm{Sr}$ ratios are reported in $\delta$-notation, with $\delta^{44 / 40} \mathrm{Ca}$ presented relative to the Ocean Scientific International Ltd. (OSIL) Atlantic seawater standard (SW) and $\delta^{88 / 86} \mathrm{Sr}$ presented relative to NIST SRM-987 strontium carbonate standard (NIST-987).

For $\delta^{44 / 40} \mathrm{Ca}$, at least $6 \mathrm{SW}$ standards and 2 NIST-915b standards were analyzed every 30 samples. For $\delta^{88 / 86} \mathrm{Sr}$, at least 6 NIST-987 standards and 2 IAPSO seawater standards were analyzed every 40 or fewer samples. During the period of study, repeated analyses yielded $\delta^{44 / 40} \mathrm{Ca}_{\mathrm{SW}}=0.000 \pm 0.003 \%$ o $\left(2 \sigma_{\text {SEM }}, \mathrm{n}=16\right)$ and $\delta^{44 / 40} \mathrm{Ca}_{915 \mathrm{~b}}=-1.134 \pm 0.002 \%_{0}\left(2 \sigma_{\text {SEM }}, \mathrm{n}=6\right)$. These results point to a remarkably good short-term reproducibility $\left(2 \sigma_{\mathrm{SD}}\right)$ ranging between $0.012 \%$ and $0.005 \%$. The current long-term values for the laboratory are $\delta^{44 / 40} \mathrm{Ca}_{\mathrm{Sw}}=0.000 \pm 0.002 \%$

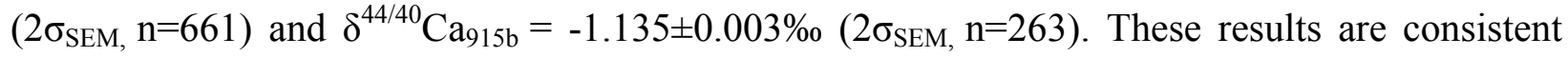
with an external reproducibility $\left(2 \sigma_{\mathrm{SD}}\right)$ of $\pm 0.05 \%$, which is the uncertainty adopted for the study. As shown below, the reproducibility of sample unknowns is better than $\pm 0.05 \%$. During the period of study, repeated measurements of NIST-987 yielded ${ }^{87} \mathrm{Sr} /{ }^{86} \mathrm{Sr}=0.710250 \pm 0.000002$ $\left(2 \sigma_{\mathrm{SEM}}, \mathrm{n}=10\right)$, consistent with the long-term mean ratio for the laboratory of $0.710251 \pm 0.000001$ $\left(2 \sigma_{\mathrm{SEM}}, \mathrm{n}=211\right)$. The overall uncertainty $\left(2 \sigma_{\mathrm{SD}}\right)$ assigned to ${ }^{87} \mathrm{Sr} /{ }^{86} \mathrm{Sr}$ ratios is \pm 0.000010 . For $\delta^{88 / 86} \mathrm{Sr}$, at least 6 NIST-987 standards and 2 IAPSO seawater standards were analyzed every 40 
or fewer samples. During the period of study, repeated analyses yielded $\delta^{88 / 86} \operatorname{Sr}_{\mathrm{NIST} 987}=$ $0.000 \pm 0.001 \%$ o $\left(2 \sigma_{\text {SEM }}, \mathrm{n}=17\right)$ and $\delta^{88 / 86} \operatorname{Sr}_{\text {IAPSO }}=0.397 \pm 0.002 \%$ o $\left( \pm 2 \sigma_{\text {SEM }}, \mathrm{n}=8\right)$. The current longterm values for the laboratory are $\delta^{88 / 86} \operatorname{Sr}_{\mathrm{NIST} 987}=0.000 \pm 0.001 \%$ o $\left( \pm 2 \sigma_{\text {SEM, }} \mathrm{n}=235\right)$ and $\delta^{88 / 86} \operatorname{Sr}_{\text {IAPSO }}=0.396 \pm 0.002 \%$ o $\left( \pm 2 \sigma_{\text {SEM }}, \mathrm{n}=133\right)$. After propagating measurement errors for ${ }^{87} \mathrm{Sr} /{ }^{86} \mathrm{Sr}$ and ${ }^{88} \mathrm{Sr} /{ }^{86} \mathrm{Sr}$ ratios, the overall uncertainty $\left(2 \sigma_{\mathrm{SD}}\right)$ assigned to $\delta^{88 / 86} \mathrm{Sr}$ is $\pm 0.020 \%$ o $\left(2 \sigma_{\mathrm{SD}}\right)$

Care was taken to ensure that uncertainties determined from the repeated analyses of standards apply to sample unknowns. Duplicates were determined by reanalyzing sample solutions $(n=4)$, as well as by re-dissolving and processing separate aliquots of powder $(n=6)$. As shown in Table DR1, duplicates agree with original analyses within the uncertainties. Duplicate measurements are shown in Fig. 1 as crosses.

\section{$\delta^{13} \mathrm{C}$ Segmentation and Stratigraphic Correlation}

Magnetostratigraphy (Tarduno et al., 1995), benthic foraminiferal biostratigraphy (Arnaud-Vanneau and Sliter, 1995), and chemostratigraphy $\left({ }^{87} \mathrm{Sr} /{ }^{86} \mathrm{Sr}\right.$ and $\delta^{13} \mathrm{C}$ ) have aided correlation of the section (Jenkyns, 1995; Jenkyns and Wilson, 1999). The Cretaceous stage boundaries are taken from Jenkyns and Wilson (1999). The nomenclature and segmentation of the $\delta^{13} \mathrm{C}$ intervals associated with OAE 1a follow Menegatti et al. (1998) and Bralower et al. (1999), based on study of the Cismon section in Italy. The C1 interval represents the pre-OAE 1a baseline of the $\delta^{13} \mathrm{C}$ curve, with a mean value of $\sim 2.4 \%$. The $\mathrm{C} 2$ interval starts with a progressive decrease of $\delta^{13} \mathrm{C}$, but values oscillate around the baseline with a slightly lower mean of $\sim 1.8 \%$. The $\mathrm{C} 3$ interval points to the minimum $\delta^{13} \mathrm{C}$ within a relatively organic-rich interval overlying the wackestone of $\mathrm{C} 2$. The $\mathrm{C} 4$ interval correlates with an abrupt positive shift towards heavier values $(\sim 4.5 \%$ ) immediately following $\mathrm{C} 3$. The C5 interval represents a segment with 
invariant $\delta^{13} \mathrm{C}$ values $(\sim 3.6 \%)$. The $\mathrm{C} 6$ interval is characterized by another step-like abrupt increase to the maximum values of the entire section $(\sim 5.4 \%)$. The $\mathrm{C} 7$ interval bears the heaviest mean value of the entire section $(\sim 4.0 \%)$. The $\mathrm{C} 8$ interval represents the subsequent drop in $\delta^{13} \mathrm{C}$ overlying C7, towards the upper Aptian.

In Figs. 3 and $\mathrm{S} 7$, the $\delta^{7} \mathrm{Li}$ values shown for Resolution Guyot are from Lechler et al. (2015). The nannoconid abundance data and ${ }^{187} \mathrm{Os} /{ }^{188} \mathrm{Os}$ ratios shown for the Cismon site are from Erba and Tremolada (2004) and Bottini et al. (2012), respectively. Atmospheric $p \mathrm{CO}_{2}$ values reconstructed from analysis of the Cau section are from Naafs et al. (2016). The $\delta^{13} \mathrm{C}$ segmentation criteria for these sections are mutually consistent. These $\delta^{13} \mathrm{C}$ segments are unchanged from the original publications and were used in our study to correlate the three sections shown in the figures.

\section{Supporting Elemental and Isotopic Results}

Fig. S1 plots $\mathrm{CaCO}_{3}$ abundances, as well as $\mathrm{Mg} / \mathrm{Ca}, \mathrm{Sr} / \mathrm{Ca}$, and $\mathrm{Mn} / \mathrm{Sr}$ ratios, versus stratigraphic height. On average, the samples have high $\mathrm{CaCO}_{3}$ abundances $(\sim 95 \mathrm{wt} \%) . \mathrm{Mg} / \mathrm{Ca}$ ratios are slightly elevated lower in the section and decrease upwards. $\mathrm{Sr} / \mathrm{Ca}$ ratios average $\sim 0.4$ $\mathrm{nmol} / \mu \mathrm{mol}$ before decreasing to $0.2 \mathrm{nmol} / \mu \mathrm{mol}$ upsection. $\mathrm{Mn} / \mathrm{Sr}$ ratios are low and modestly decrease upsection from 0.3 to $0.2 \mathrm{~mol} / \mathrm{mol}$.

Figs. S2 - S3 cross plot various parameters. Both ordinary least squares (OLS) and standardized major axis (SMA) linear regression models were employed to evaluate the statistical significance of apparent correlations. Unlike the OLS model, the SMA model considers that both $\mathrm{x}$ and $\mathrm{y}$ variables have error. All regression statistics presented here are from the SMA model, but no differences between the two models were observed. No significant correlations exist, with the exception of the following: $\delta^{44 / 40} \mathrm{Ca}$ vs. $\delta^{88 / 86} \mathrm{Sr}\left(R^{2}=0.66, p=\right.$ 
$\left.7.7 \times 10^{-8}\right), \delta^{44 / 40} \mathrm{Ca}$ vs. $\mathrm{Sr} / \mathrm{Ca}\left(R^{2}=0.40, p=1.3 \times 10^{-4}\right)$, and $\delta^{88 / 86} \mathrm{Sr}$ vs. $\mathrm{Ca} / \mathrm{Sr}\left(R^{2}=0.31, p=\right.$ $\left.1.0 \times 10^{-3}\right)$.

\section{Sr Isotope Equilibration Sensitivity Analysis}

Previous investigations have shown that $\mathrm{Sr}$ isotope equilibration between recrystallizing carbonate sediments and pore fluids only shifts ${ }^{87} \mathrm{Sr} /{ }^{86} \mathrm{Sr}$ ratios by $10-50 \mathrm{ppm}$ (e.g., Richter and DePaolo, 1988; Richter and Liang, 1993). Negligible effects are predicted for $\delta^{88 / 86} \mathrm{Sr}$ because the mixing end-members have less contrast in stable $\mathrm{Sr}$ isotope space. To illustrate this point, a simple two-component mixing model is employed to examine how shifts in carbonate $\delta^{88 / 86} \mathrm{Sr}$ values $\left(4^{88 / 86} \mathrm{Sr}\right)$ correspond to shifts in carbonate ${ }^{87} \mathrm{Sr} /{ }^{86} \mathrm{Sr}$ ratios $\left(4^{87} \mathrm{Sr}{ }^{86} \mathrm{Sr}\right)$. The equations are:

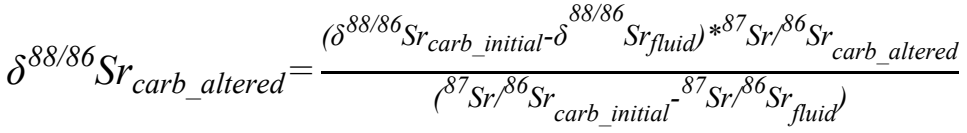

$$
\begin{aligned}
& \delta^{88 / 86} S r_{\text {carb_altered }}=\delta^{88 / 86} S r_{\text {carb_initial }}+\Delta^{88 / 86} \mathrm{Sr} \\
& { }^{87} \mathrm{Sr}{ }^{86} \mathrm{Sr}_{\text {carb_altered }}={ }^{87} \mathrm{Sr} /{ }^{86} \mathrm{Sr} r_{\text {carb_initial }}+\Delta^{87} \mathrm{Sr} /{ }^{86} \mathrm{Sr} \text {, }
\end{aligned}
$$

where carb_initial refers to the initial carbonate before recrystallization, carb_altered denotes the altered carbonate after recrystallization, and fluid refers to pore water. Two example

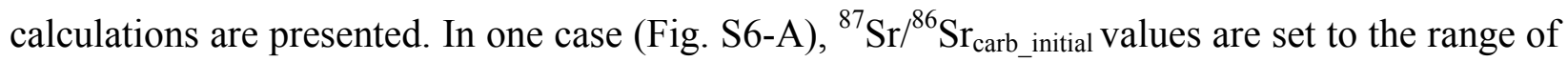
ratios measured for the present dataset and all other parameters are set to modern values. In the

second case (Fig. S6-B), ${ }^{87} \mathrm{Sr} /{ }^{86} \mathrm{Sr}_{\text {carb } \_ \text {initial }}$ is set to the average for the present dataset, ${ }^{87} \mathrm{Sr}^{86} \mathrm{Sr}_{\text {fluid }}$ is allowed to range from 0.7082 to 0.7092 , and the remaining two parameters are set to modern values. As Figs. S6-A and B show, $\Delta^{87} S r{ }^{86} S r$ values ranging up to $100 \mathrm{ppm}$ yield $\Delta^{88 / 86} \mathrm{Sr}$ values 
no higher than $0.03 \%$, which is only $0.01 \%$ higher than the long-term external reproducibility of the stable $\mathrm{Sr}$ isotope method and smaller than the total range of $\delta^{88 / 86} \mathrm{Sr}$ variation measured for the samples $(0.12 \%)$. 

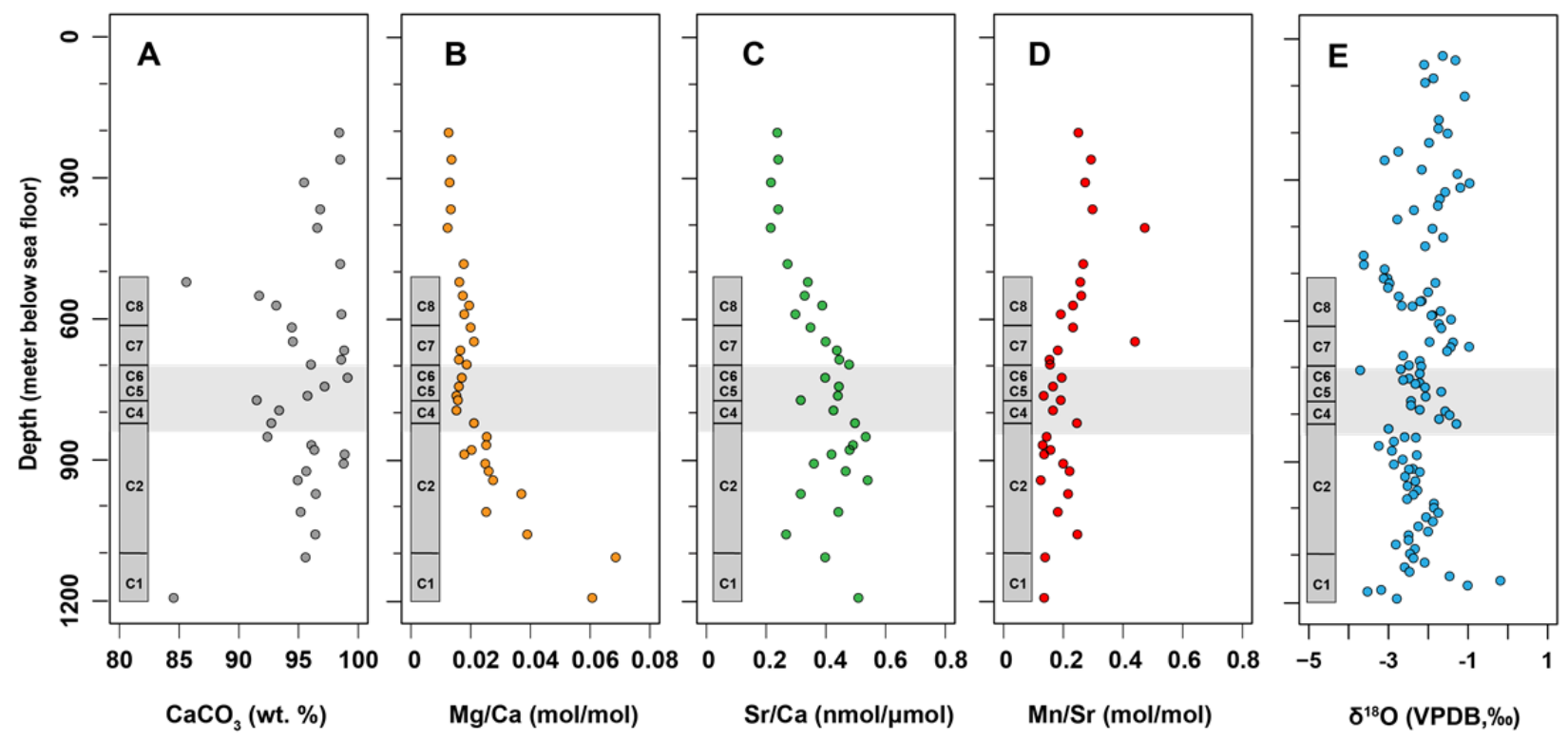

Figure S1 Stratigraphic height vs (A) $\mathrm{CaCO}_{3}$ abundance, (B) $\mathrm{Mg} / \mathrm{Ca}(\mathrm{mol} / \mathrm{mol}),(\mathrm{C}) \mathrm{Sr} / \mathrm{Ca}(\mathrm{nmol} / \mu \mathrm{mol})$, (D) $\mathrm{Mn} / \mathrm{Sr}(\mathrm{mol} / \mathrm{mol})$, and (E) $\delta^{18} \mathrm{O}$ in bulk carbonate samples from ODP Hole 866A at Resolution Guyot. 

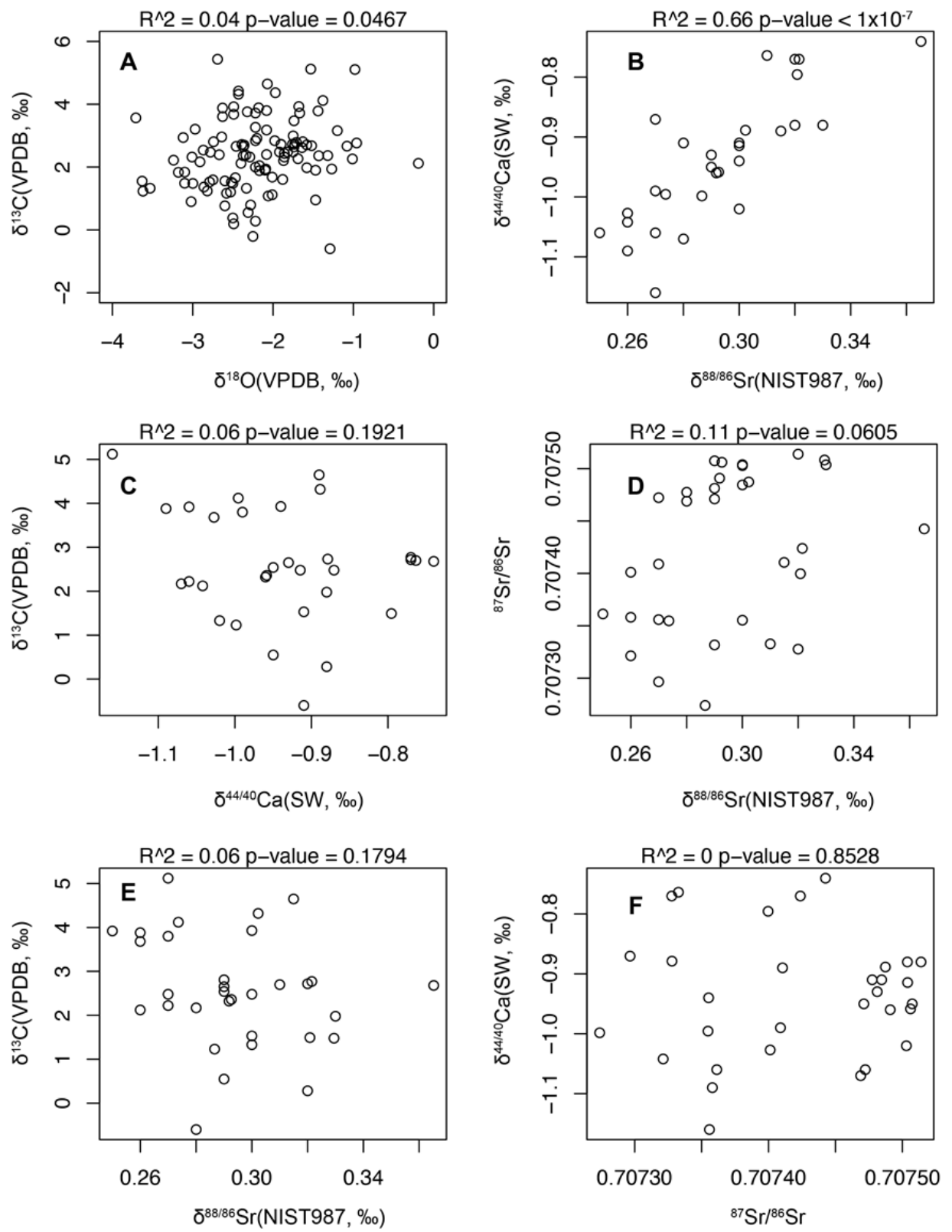

Figure S2 Cross-plots of various parameters measured for bulk carbonate samples from ODP Hole 866A at Resolution Guyot. $R^{2}$ and $p$-value are from the SMA regression model. (A) $\delta^{13} \mathrm{C}$ vs $\delta^{18} \mathrm{O}$, (B) $\delta^{44 / 40} \mathrm{Ca}$ vs $\delta^{88 / 86} \mathrm{Sr}$, (C) $\delta^{13} \mathrm{C}$ vs $\delta^{44 / 40} \mathrm{Ca}$, (D) ${ }^{87} \mathrm{Sr} /{ }^{86} \mathrm{Sr}$ vs $\delta^{88 / 86} \mathrm{Sr}$, (E) $\delta^{13} \mathrm{C}$ vs $\delta^{88 / 86} \mathrm{Sr}$, and (F) $\delta^{44 / 40} \mathrm{Ca}$ vs ${ }^{87} \mathrm{Sr} /{ }^{86} \mathrm{Sr}$. 

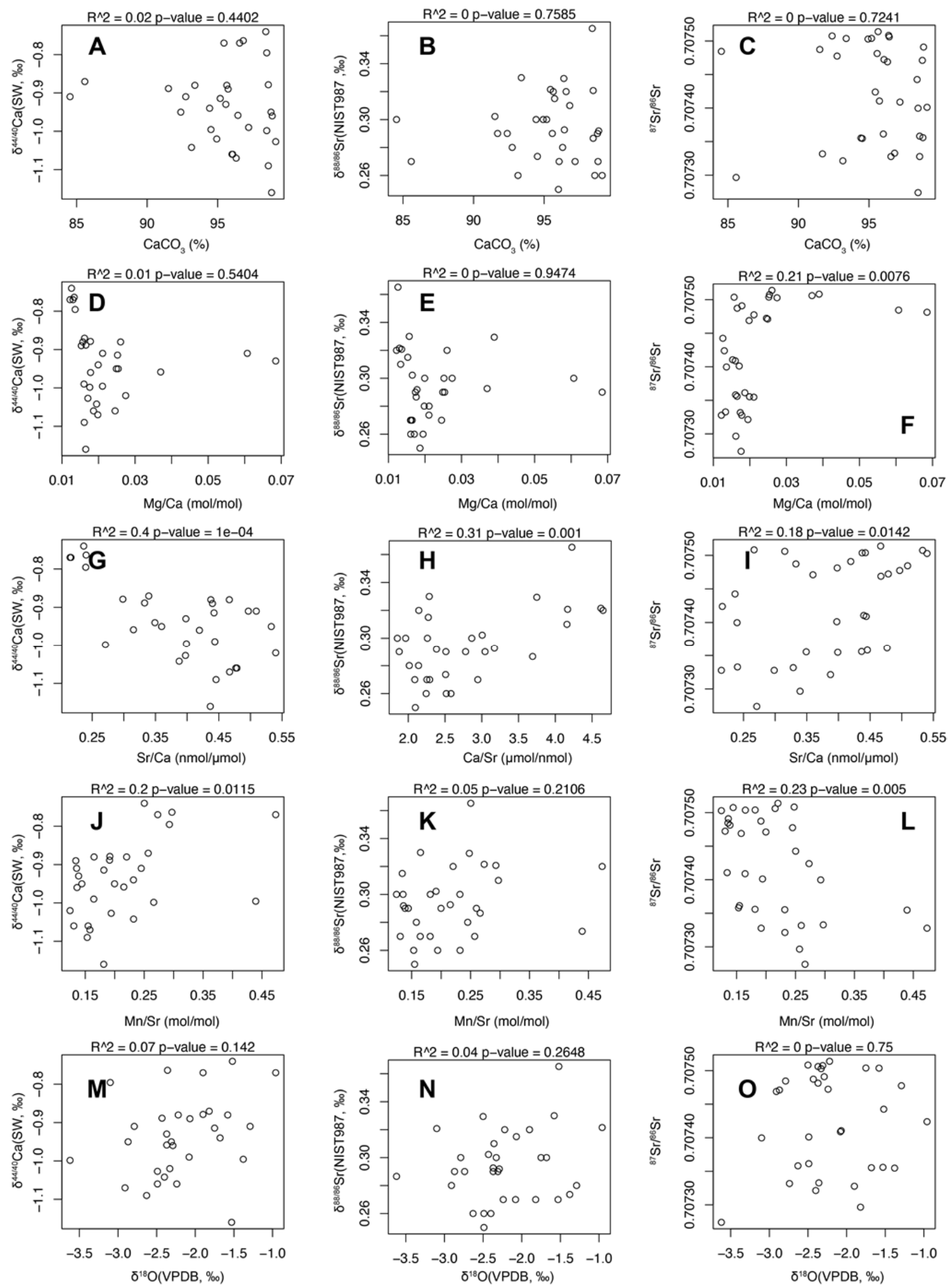

Figure S3 Cross-plots of isotope ratios and selected lithological proxies in bulk carbonate samples from the ODP Hole 866A at Resolution Guyot. $R^{2}$ and $p$-value are from the SMA regression model. (A) $\delta^{44 / 40} \mathrm{Ca}$ vs $\mathrm{CaCO}_{3}$, (B) $\delta^{88 / 86} \mathrm{Sr}$ vs $\mathrm{CaCO}_{3}$, (C) ${ }^{87} \mathrm{Sr} /{ }^{86} \mathrm{Sr}$ vs $\mathrm{CaCO}_{3}$, (D) $\delta^{44 / 40} \mathrm{Ca}$ vs $\mathrm{Mg} / \mathrm{Ca}$, (E) $\delta^{88 / 86} \mathrm{Sr}$ vs $\mathrm{Mg} / \mathrm{Ca}$, (F) ${ }^{87} \mathrm{Sr} /{ }^{86} \mathrm{Sr}$ vs $\mathrm{Mg} / \mathrm{Ca},(\mathrm{G}) \delta^{44 / 40} \mathrm{Ca}$ vs $\mathrm{Sr} / \mathrm{Ca},(\mathrm{H}) \delta^{88 / 86} \mathrm{Sr}$ vs Ca/Sr, (I) ${ }^{87} \mathrm{Sr} /{ }^{86} \mathrm{Sr}$ vs $\mathrm{Sr} / \mathrm{Ca}$, (J) $\delta^{44 / 40} \mathrm{Ca}$ vs $\mathrm{Mn} / \mathrm{Sr},(\mathrm{K})$ $\delta^{88 / 86} \mathrm{Sr}$ vs $\mathrm{Mn} / \mathrm{Sr}$, (L) ${ }^{87} \mathrm{Sr} /{ }^{86} \mathrm{Sr}$ vs $\mathrm{Mn} / \mathrm{Sr}$, (M) $\delta^{44 / 40} \mathrm{Ca}$ vs $\delta^{18} \mathrm{O}$, (N) $\delta^{88 / 86} \mathrm{Sr}$ vs $\delta^{18} \mathrm{O}$, and (O) ${ }^{87} \mathrm{Sr} /{ }^{86} \mathrm{Sr}$ vs $\delta^{18} \mathrm{O}$. 
This study

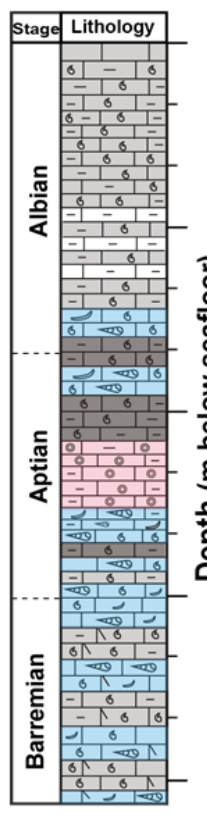

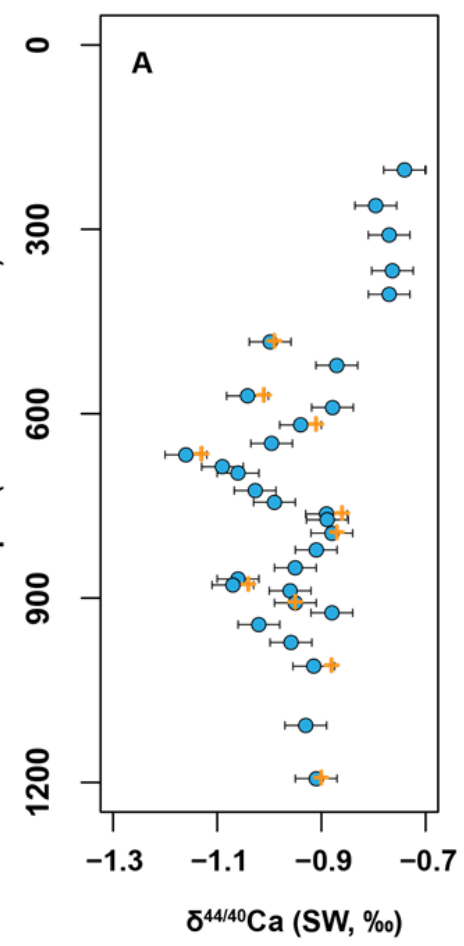

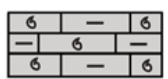

Wackestone

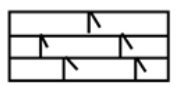

Dolomitic Limestone

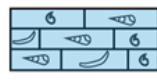

Packstone
Blättler et al., 2011
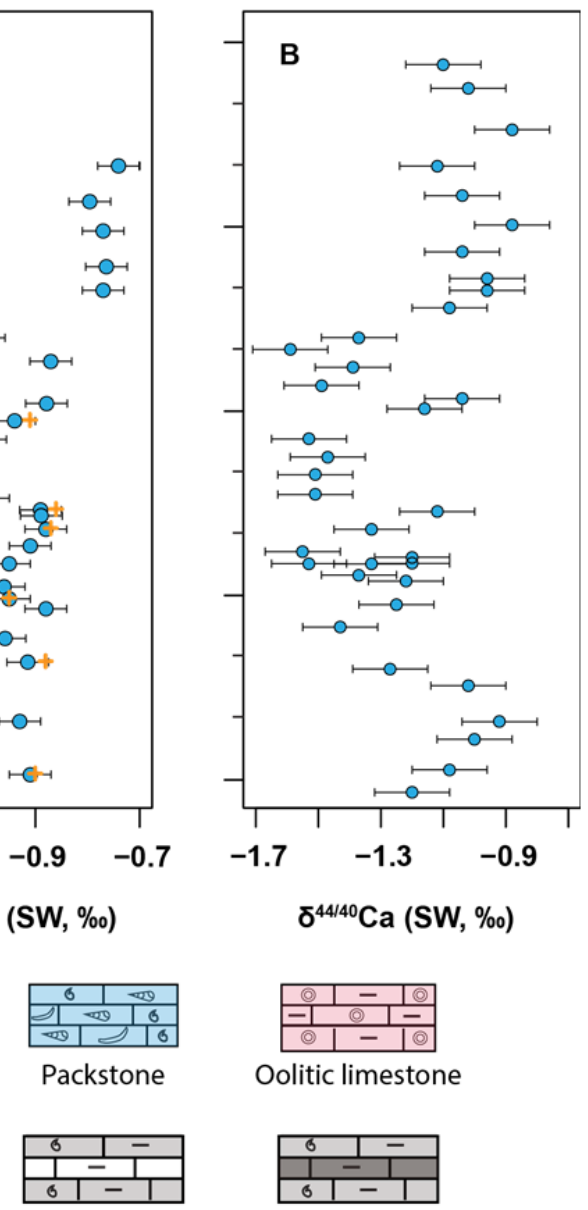

Packstone with white mud layers organic-rich intervals

Figure S4 $\delta^{44 / 40} \mathrm{Ca}$ values from Hole $866 \mathrm{~A}$ of ODP Leg143 at Resolution Guyot, mid-Pacific Ocean. A) $\delta^{44 / 40} \mathrm{Ca}$ values from this study with error bars of $\pm 0.05 \%$. Crosses represent duplicate measurements. B) $\delta^{44 / 40} \mathrm{Ca}$ values from Blättler et al. (2011) with error bars of $\pm 0.12 \%$. Blättler et al. (2011) measured $\delta^{44 / 42} \mathrm{Ca}$ relative to NIST-915a. The data and corresponding error bars of $\pm 0.06 \%$ were converted using the equation: $\delta^{44 / 40} \mathrm{Ca}_{\mathrm{SW}}=\delta^{44 / 42} \mathrm{Ca}_{915 \mathrm{a}} / 0.488-1.86$, where 0.488 assumes mass fractionation follows a kinetic law and 1.86 is the value the Northwestern Laboratory measures for 915a relative to seawater (e.g., Du Vivier et al., 2015). 


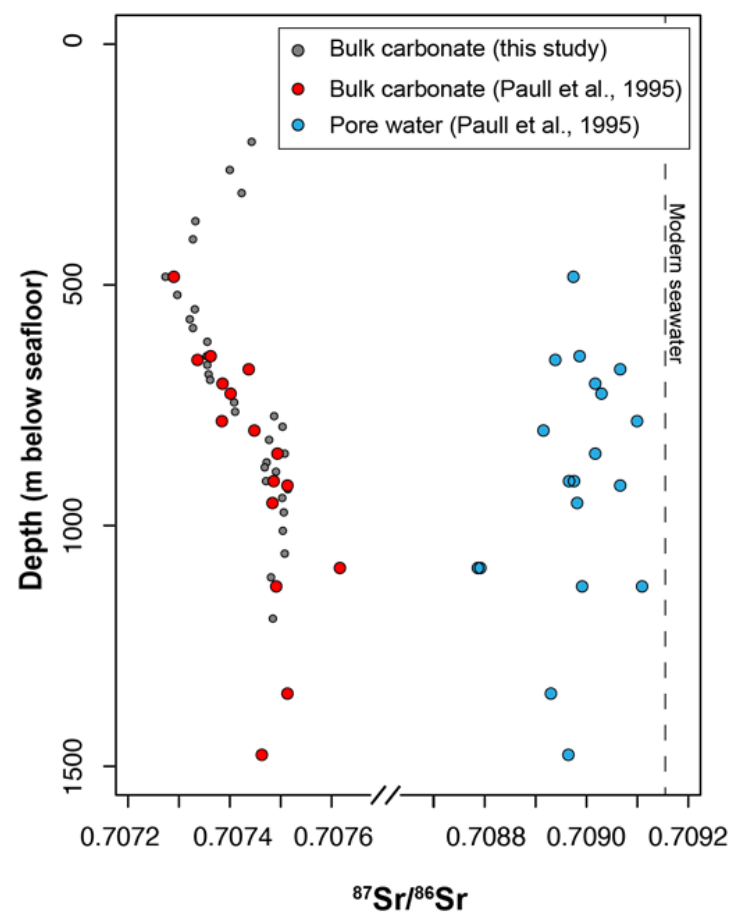

Figure S5 ${ }^{87} \mathrm{Sr} /{ }^{86} \mathrm{Sr}$ records of porewater (Paull et al., 1995) and bulk carbonate (This study; Paull et al., 1995).
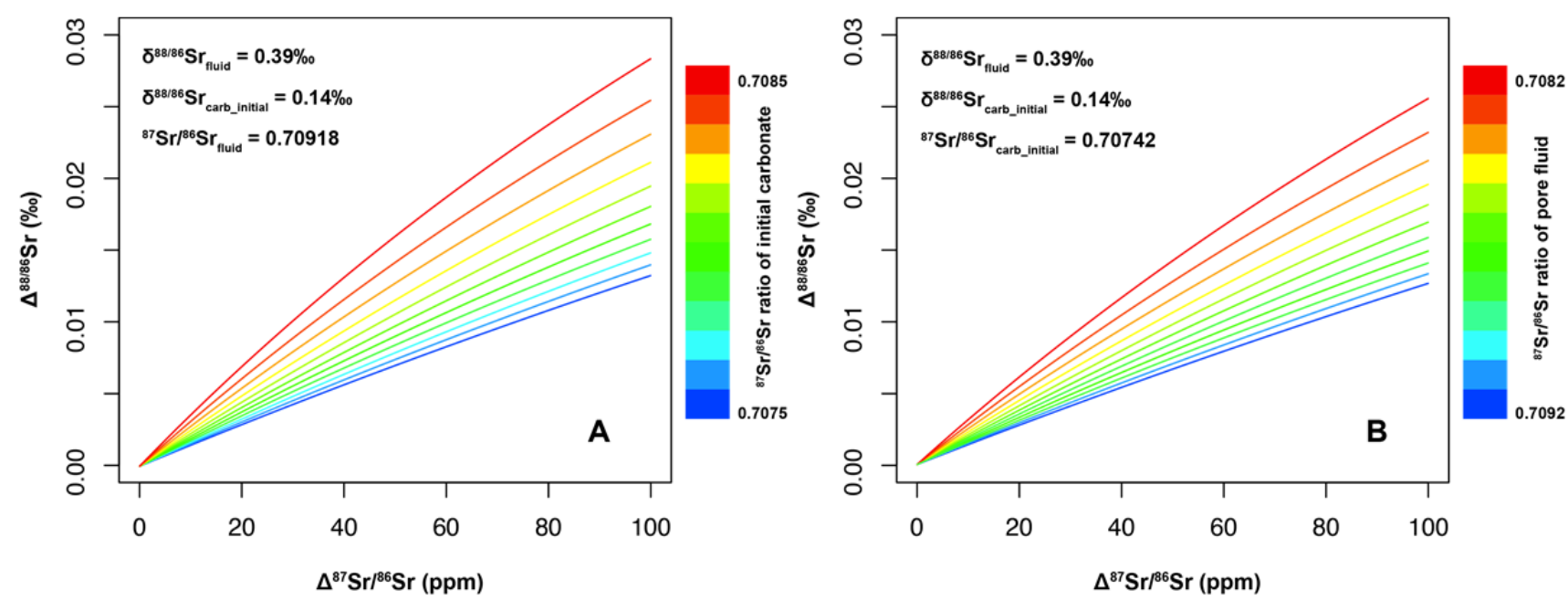

Figure S6 Sensitivity test for $\delta^{88 / 86} \mathrm{Sr}$ response to early diagenetic ${ }^{87} \mathrm{Sr} /{ }^{86} \mathrm{Sr}$ shifts. A) ${ }^{87} \mathrm{Sr}^{86} \mathrm{Sr}_{\text {carb_initial }}$ values set to the range of ratios measured for the present dataset and all other parameters set to modern values. B) ${ }^{87} \mathrm{Sr}^{86}{ }^{8 \mathrm{Sr}_{\text {carb initial }}}$ set to the average for the present dataset, ${ }^{87} \mathrm{Sr}^{86}{ }^{86} \mathrm{Sr}_{\text {fluid }}$ allowed to range from 0.7082 to 0.7092 , and the remaining two parameters set to modern values. 


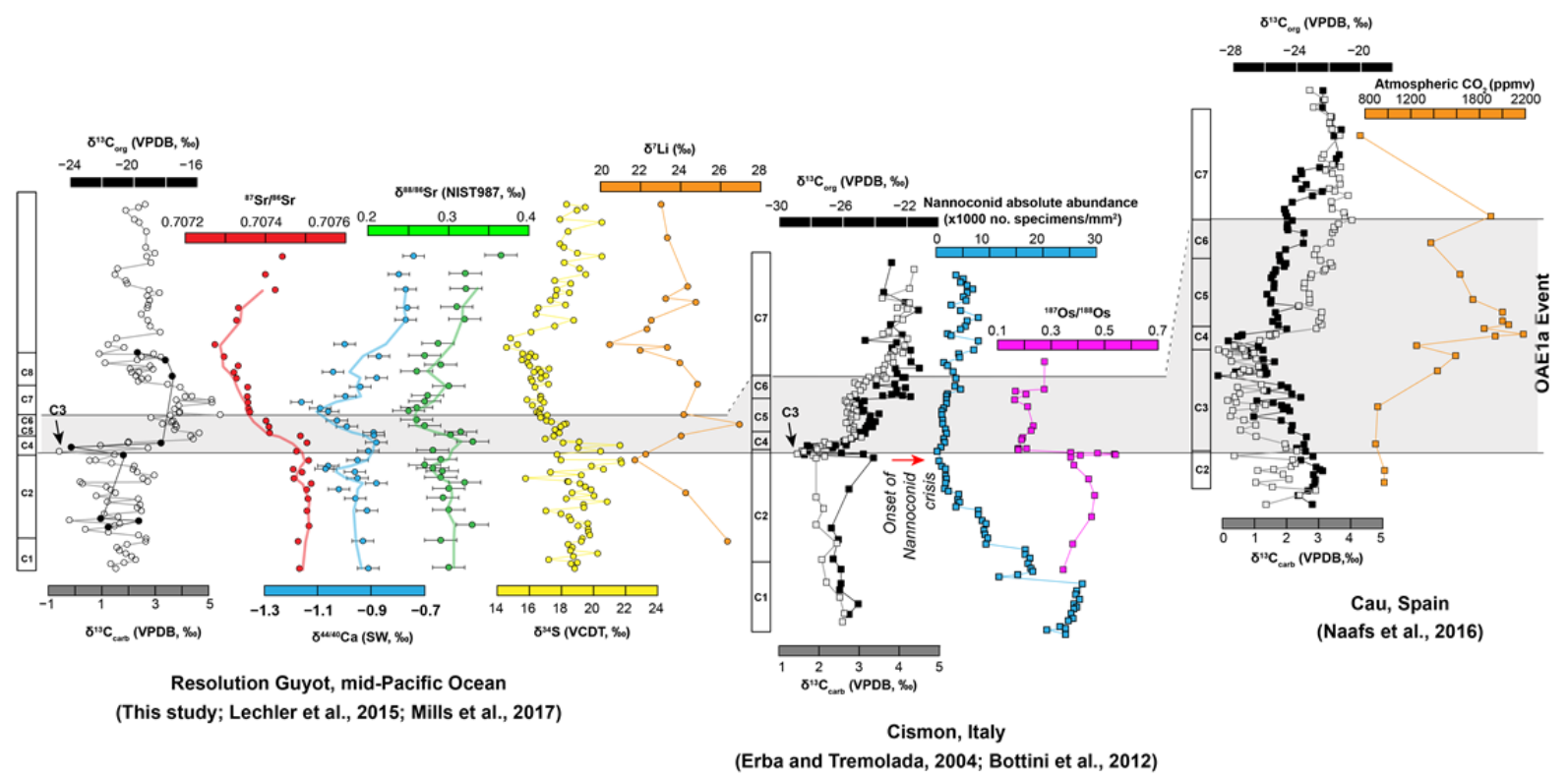

Figure S7 Stratigraphic correlation of various geochemical proxy data for the entire study interval. Fig. 3 in the main text shows the OAE 1a interval. 
Table S1 Elemental, C, O, Ca, and Sr isotope geochemistry of carbonate samples from Hole 866A, ODP Leg 143, Resolution Guyot, mid-Pacific

\begin{tabular}{|c|c|c|c|c|c|c|}
\hline $\begin{array}{l}\text { Depth } \\
\text { (mbsf) }\end{array}$ & $\begin{array}{c}\delta^{13} \mathbf{C} \\
(\text { VPDB, \%o) }\end{array}$ & $\begin{array}{c}\delta^{18} \mathbf{O} \\
(\text { VPDB, \%o) }\end{array}$ & $\begin{array}{l}\delta^{44 / 40} \mathrm{Ca} \\
(\mathrm{SW}, \%)\end{array}$ & $\begin{array}{c}\delta^{44 / 40} \mathrm{Ca} \\
(\mathrm{SW}, \% \text { \%) } \\
\text { Duplicate }\end{array}$ & $\begin{array}{c}\delta^{88 / 86} \mathrm{Sr} \\
\text { (NIST987, \%o) }\end{array}$ & $\begin{array}{c}\delta^{88 / 86} \mathbf{S r} \\
\text { (NIST987, \%o) } \\
\text { Duplicate }\end{array}$ \\
\hline 203.40 & 2.72 & -1.61 & -0.74 & & 0.37 & \\
\hline 261.33 & 1.34 & -3.24 & -0.80 & & 0.32 & 0.33 \\
\hline 309.25 & 2.77 & -1.12 & -0.77 & & 0.32 & \\
\hline 367.34 & 2.7 & -2.36 & -0.76 & & 0.31 & \\
\hline 405.83 & 2.68 & -1.8 & -0.77 & & 0.32 & \\
\hline 483.15 & 1.28 & -3.41 & -1.00 & -0.99 & 0.29 & 0.28 \\
\hline 521.4 & 2.6 & -1.82 & -0.87 & & 0.27 & \\
\hline 550.52 & 2.9 & -2.68 & & & 0.29 & \\
\hline 571.15 & 2.04 & -2.21 & -1.04 & -1.01 & 0.26 & \\
\hline 589.87 & 2.76 & -1.96 & -0.88 & & & \\
\hline 618.34 & 4 & -1.7 & -0.94 & -0.91 & 0.30 & \\
\hline 648.40 & 4.2 & -1.38 & -1.00 & & 0.27 & 0.28 \\
\hline 666.82 & 5.12 & -1.6 & -1.16 & -1.13 & 0.27 & \\
\hline 686.30 & 3.7 & -2.67 & -1.09 & & 0.26 & \\
\hline 696.8 & 3.92 & -2.37 & -1.06 & & 0.25 & \\
\hline 725.1 & 3.68 & -2.4 & -1.03 & & 0.26 & \\
\hline 744.15 & 3.8 & -2.08 & -0.99 & & 0.27 & 0.27 \\
\hline 763.2 & 4.65 & -1.98 & -0.89 & -0.86 & 0.32 & \\
\hline 772.65 & 4.32 & -2.43 & -0.89 & & 0.30 & \\
\hline 794.45 & 2 & -1.72 & -0.88 & -0.87 & 0.33 & \\
\hline 821.6 & -0.64 & -1.3 & -0.91 & & 0.28 & 0.29 \\
\hline 850.81 & 0.52 & -2.3 & -0.95 & & 0.29 & \\
\hline 868.9 & 2.22 & -2.31 & -1.06 & & 0.27 & \\
\hline 878.8 & 2.17 & -2.86 & -1.07 & -1.04 & 0.28 & 0.29 \\
\hline 888.17 & 2.3 & -2.4 & -0.96 & & 0.29 & \\
\hline 907.85 & 2.54 & -2.87 & -0.95 & -0.95 & 0.29 & \\
\hline 924 & 0.31 & -2.54 & -0.88 & & 0.32 & \\
\hline 943.13 & 1.33 & -2.51 & -1.02 & & 0.30 & \\
\hline 972.33 & 2.4 & -2.25 & -0.96 & & 0.29 & \\
\hline 1010.93 & 2.53 & -1.81 & -0.91 & -0.88 & 0.30 & \\
\hline 1058.20 & 1.5 & -2.59 & & & 0.33 & 0.32 \\
\hline 1107.2 & 2.65 & -2.27 & -0.93 & & 0.29 & \\
\hline 1193.75 & 1.49 & -2.84 & -0.91 & -0.90 & 0.30 & \\
\hline
\end{tabular}


Table S1 Continued.

\begin{tabular}{|c|c|c|c|c|c|c|}
\hline${ }^{87} \mathrm{Sr} /{ }^{86} \mathrm{Sr}$ & $\begin{array}{l}{ }^{87} \mathrm{Sr} /{ }^{86} \mathrm{Sr} \\
\text { Duplicate }\end{array}$ & $\begin{array}{c}\mathrm{Ca} \\
(\mu \mathrm{mol} / \mathrm{g})\end{array}$ & $\begin{array}{c}\mathrm{Na} \\
(\mu \mathrm{mol} / \mathrm{g})\end{array}$ & $\begin{array}{c}\mathrm{Mg} \\
(\mu \mathrm{mol} / \mathrm{g})\end{array}$ & $\begin{array}{c}\mathrm{Sr} \\
(\mathrm{nmol} / \mathrm{g})\end{array}$ & $\begin{array}{c}\text { Mn } \\
(\mathrm{nmol} / \mathrm{g})\end{array}$ \\
\hline 0.70744 & & 9841 & 36 & 124 & 2328 & 582 \\
\hline 0.70740 & & 9847 & 35 & 134 & 2362 & 692 \\
\hline 0.70742 & & 9544 & 36 & 124 & 2066 & 564 \\
\hline 0.70733 & 0.70733 & 9681 & 31 & 129 & 2328 & 692 \\
\hline 0.70733 & & 9656 & 44 & 118 & 2077 & 983 \\
\hline 0.70727 & 0.70727 & 9848 & 64 & 173 & 2667 & 710 \\
\hline 0.70730 & & 8559 & 73 & 138 & 2905 & 746 \\
\hline 0.70733 & & 9170 & 108 & 159 & 3012 & 783 \\
\hline 0.70732 & & 9315 & 100 & 181 & 3609 & 837 \\
\hline 0.70733 & & 9859 & 57 & 175 & 2943 & 564 \\
\hline 0.70736 & & 9443 & 63 & 188 & 3297 & 764 \\
\hline 0.70735 & & 9452 & 61 & 199 & 3770 & 1656 \\
\hline 0.70736 & 0.70735 & 9882 & 69 & 163 & 4314 & 783 \\
\hline 0.70736 & & 9859 & 65 & 159 & 4394 & 673 \\
\hline 0.70736 & & 9602 & 51 & 179 & 4580 & 710 \\
\hline 0.70740 & & 9911 & 47 & 169 & 3938 & 764 \\
\hline 0.70741 & & 9719 & 45 & 156 & 4314 & 710 \\
\hline 0.70741 & & 9574 & 54 & 146 & 4212 & 564 \\
\hline 0.70749 & & 9151 & 49 & 151 & 3045 & 582 \\
\hline 0.70750 & & 9339 & 54 & 147 & 4085 & 673 \\
\hline 0.70748 & 0.70748 & 9274 & 98 & 196 & 4607 & 1129 \\
\hline 0.70751 & & 9239 & 89 & 234 & 4924 & 710 \\
\hline 0.70747 & & 9606 & 70 & 236 & 4599 & 601 \\
\hline 0.70747 & & 9631 & 67 & 191 & 4499 & 710 \\
\hline 0.70749 & & 9887 & 30 & 176 & 4147 & 564 \\
\hline 0.70747 & & 9878 & 24 & 246 & 3553 & 710 \\
\hline 0.70751 & & 9564 & 87 & 249 & 4463 & 983 \\
\hline 0.70750 & 0.70750 & 9493 & 88 & 261 & 5126 & 637 \\
\hline 0.70751 & & 9643 & 66 & 357 & 3041 & 655 \\
\hline 0.70750 & & 9518 & 39 & 240 & 4211 & 764 \\
\hline 0.70751 & & 9640 & 59 & 376 & 2571 & 637 \\
\hline 0.70748 & & 9557 & 63 & 655 & 3804 & 528 \\
\hline 0.70748 & & 8454 & 24 & 513 & 4305 & 582 \\
\hline
\end{tabular}


Table S2 Slopes, intercepts, coefficients of determination, and p-values of datasets examined in Fig. 2

\begin{tabular}{|c|c|c|c|c|c|c|}
\hline & Dataset & Slope & Intercept & $R^{2}$ & $p$-value & Reference \\
\hline \multirow{4}{*}{$\begin{array}{l}\delta^{44 / 40} \mathrm{Ca} \\
\text { vs [Sr] } \\
\text { (Fig. 2A) }\end{array}$} & $\begin{array}{l}\text { OAE 1a } \\
\text { carbonate }\end{array}$ & $\begin{array}{l}-0.00091 \\
\pm 0.00018 \\
\end{array}$ & $-0.64 \pm 0.06$ & 0.47 & $2.1 \times 10^{-5}$ & This study \\
\hline & Inorganic calcite & $\begin{array}{l}-0.00094 \\
\pm 0.00005\end{array}$ & $-0.85 \pm 0.05$ & 0.91 & $2.2 \times 10^{-16}$ & Tang et al. (2008) \\
\hline & $\begin{array}{l}\text { Silurian } \\
\text { carbonate }\end{array}$ & $\begin{array}{l}-0.00097 \\
\pm 0.00017 \\
\end{array}$ & $-0.92 \pm 0.09$ & 0.53 & $1.1 \times 10^{-6}$ & Farkaš et al. (2016) \\
\hline & P-Tr carbonate & $\begin{array}{l}-0.00025 \\
\pm 0.00003\end{array}$ & $-1.21 \pm 0.02$ & 0.35 & $3.1 \times 10^{-5}$ & Wang et al. (2019) \\
\hline \multirow{3}{*}{$\begin{array}{l}\delta^{44 / 40} \mathrm{Ca} \\
\text { vs } \delta^{88 / 86} \mathrm{Sr} \\
\text { (Fig. 2B) }\end{array}$} & $\begin{array}{l}\text { OAE 1a } \\
\text { carbonate }\end{array}$ & $\begin{array}{c}0.194 \\
\pm 0.027 \\
\end{array}$ & $0.475 \pm 0.025$ & 0.66 & $7.7 \times 10^{-8}$ & This study \\
\hline & Inorganic calcite & $\begin{array}{c}0.185 \\
\pm 0.019 \\
\end{array}$ & $0.286 \pm 0.033$ & 0.96 & $6.0 \times 10^{-4}$ & Böhm et al. (2012) \\
\hline & P-Tr carbonate & $\begin{array}{c}0.131 \\
\pm 0.082\end{array}$ & $0.560 \pm 0.109$ & 0.07 & 0.12 & Wang et al. (2019) \\
\hline
\end{tabular}

\section{Supplemental References}

Andrews, M.G., and Jacobson, A.D., 2017, The radiogenic and stable Sr isotope geochemistry of basalt weathering in Iceland: Role of hydrothermal calcite and implications for long-term climate regulation: Geochimica et Cosmochimica Acta, v. 215, p. 247-262, doi:10.1016/j.gca.2017.08.012.

Andrews, M.G., Jacobson, A.D., Lehn, G.O., Horton, T.W., and Craw, D., 2016, Radiogenic and stable $\mathrm{Sr}$ isotope ratios $\left({ }^{87} \mathrm{Sr} /{ }^{86} \mathrm{Sr}, \delta^{88 / 86} \mathrm{Sr}\right)$ as tracers of riverine cation sources and biogeochemical cycling in the Milford Sound region of Fiordland, New Zealand: Geochimica et Cosmochimica Acta, v. 173, p. 284-303, doi:10.1016/j.gca.2015.10.005.

Arnaud-Vanneau, A., and Sliter, W. V, 1995, Early Cretaceous shallow-water benthic foraminifers and fecal pellets from Leg 143 compared with coeval faunas from the Pacific Basin, Central America, and the Tethys: Northwest Pacific atolls and guyots, in Proceedings of the Ocean Drilling Program. Scientific Results, v. 142, p. 537-564.

Blättler, C.L., Jenkyns, H.C., Reynard, L.M., and Henderson, G.M., 2011, Significant increases in global weathering during Oceanic Anoxic Events 1a and 2 indicated by calcium isotopes: Earth and Planetary Science Letters, v. 309, p. 77-88, doi:10.1016/j.epsl.2011.06.029.

Böhm, F., Eisenhauer, A., Tang, J., Dietzel, M., Krabbenhöft, A., Kisakürek, B., and Horn, C., 2012, Strontium isotope fractionation of planktic foraminifera and inorganic calcite: Geochimica et Cosmochimica Acta, v. 93, p. 300-314, doi:10.1016/j.gca.2012.04.038.

Bralower, T.J., Cobabe, E., Clement, B., Sliter, W. V., Osburn, C.L., and Longoria, J., 1999, The record of global change in mid-Cretaceous (Barremian-Albian) sections from the Sierra Madre, Northeastern Mexico: Journal of Foraminiferal Research, v. 29, p. 418-437. 
Du Vivier, A.D.C., Jacobson, A.D., Lehn, G.O., Selby, D., Hurtgen, M.T., and Sageman, B.B., 2015, Ca isotope stratigraphy across the Cenomanian-Turonian OAE 2: Links between volcanism, seawater geochemistry, and the carbonate fractionation factor: Earth and Planetary Science Letters, v. 416, p. 121-131, doi:10.1016/j.eps1.2015.02.001.

Erba, E., and Tremolada, F., 2004, Nannofossil carbonate fluxes during the Early Cretaceous: Phytoplankton response to nutrification episodes, atmospheric $\mathrm{CO}_{2}$, and anoxia . Paleoceanography, 19(1). doi:10.1029/2003pa000884.

Farkaš, J., Frýda, J., and Holmden, C., 2016, Calcium isotope constraints on the marine carbon cycle and $\mathrm{CaCO}_{3}$ deposition during the late Silurian (Ludfordian) positive $\delta^{13} \mathrm{C}$ excursion: Earth and Planetary Science Letters, v. 451, p. 31-40, doi:10.1016/j.epsl.2016.06.038.

Flood, P.G., and Chivas, A.R., 1995, Origin of massive dolomite, Leg 143, Hole 866A, Resolution Guyot, Mid-Pacific Mountains: Northwest Pacific atolls and guyots, in Proceedings of the Ocean Drilling Program. Scientific results, v. 142, p. 161-169.

Jenkyns, H.C., 1995, Carbon-Isotope Stratigraphy and Paleoceanographic Significance of the Lower Cretaceous Shallow-Water Carbonates of Resolution Guyot, Mid-Pacific Mountains: Proceedings of the Ocean Drilling Program, 143 Scientific Results, v. 143, doi:10.2973/odp.proc.sr.143.213.1995.

Jenkyns, H.C., and Strasser, A., 1995, Lower Cretaceous oolites from the Mid-Pacific Mountains (Resolution Guyot, Site 866): Proc., scientific results, ODP, Leg 143, northwest Pacific atolls and guyots, p. 111-118, doi:10.2973/odp.proc.sr.143.211.1995.

Jenkyns, H.C., and Wilson, P.A., 1999, Stratigraphy, paleoceanography, and evolution of Cretaceous Pacific guyots: Relics from a greenhouse Earth: American Journal of Science, v. 299, p. 341-392, doi:10.2475/ajs.299.5.341.

Menegatti, A.P., Weissert, H., Brown, R.S., Tyson, R. V., Farrimond, P., Strasser, A., and Caron, M., 1998, High-resolution $\delta^{13} \mathrm{C}$ stratigraphy through the Early Aptian "Livello selli" of the Alpine tethys: Paleoceanography, v. 13, p. 530-545, doi:10.1029/98PA01793.

Mills, J.V., Gomes, M.L., Kristall, B., Sageman, B.B., Jacobson, A.D. and Hurtgen, M.T., 2017. Massive volcanism, evaporite deposition, and the chemical evolution of the Early Cretaceous ocean. Geology, 45(5), pp.475-478. doi: 10.1130/G38667.1

Naafs, B.D.A., Castro, J.M., De Gea, G.A., Quijano, M.L., Schmidt, D.N., and Pancost, R.D., 2016, Gradual and sustained carbon dioxide release during Aptian Oceanic Anoxic Event 1a: Nature Geoscience, v. 9, p. 135-139, doi:10.1038/ngeo2627.

Paull, C.K., Fullagar, P.D., Bralower, T.J., and Rohl, U., 1995, Seawater ventilation of midPacific guyots drilled during Leg 143: Proc., scientific results, ODP, Leg 143, northwest Pacific atolls and guyots, v. 143, p. 231-241, doi:10.2973/odp.proc.sr.143.222.1995.

Richter, F.M., and DePaolo, D.J., 1988, Diagenesis and Sr isotopic evolution of seawater using data from DSDP 590B and 575: Earth and Planetary Science Letters, v. 90, p. 382-394, doi:10.1016/0012-821X(88)90137-9.

Richter, F.M., and Liang, Y., 1993, The rate and consequences of Sr diagenesis in deep-sea carbonates: Earth and Planetary Science Letters, v. 117, p. 553-565, doi:10.1016/0012$821 \mathrm{X}(93) 90102-\mathrm{F}$. 
Rohl, U., and Strasser, A., 1995, Diagenetic alterations and geochemical trends in early Cretaceous shallow-water limestones of Allison and Resolution Guyots (Sites 865 to 868): Proc., scientific results, ODP, Leg 143, northwest Pacific atolls and guyots, v. 143, p. 197 229, doi:10.2973/odp.proc.sr.143.224.1995.

Sager, W.W., Winterer, E.L., Firth, J. V, and others, A. 23, 1993, Proceedings of the Ocean Drilling Program, Vol. 143, Initial Reports, Northwest Pacific Atolls and Guyots.

Sliter, W. V, 1995, Cretaceous planktonic foraminifers from Sites 865, 866, and 869: A synthesis of Cretaceous pelagic sedimentation in the central Pacific Ocean basin, in Proceedings of the Ocean Drilling Program, Scientific Results, v. 143, p. 15-30.

Swinburne, N.H.M., Masse, J.-P., Winterer, E.L., Sager, W.W., Firth, J. V, and Sinton, J.M., 1995, Early Cretaceous rudist fauna of Allison and Resolution Guyots, Mid-Pacific Mountains, in Proceedings of the Ocean Drilling Program, Scientific Results, v. 143, p. 314.

Tang, J., Dietzel, M., Böhm, F., Köhler, S.J., and Eisenhauer, A., 2008, $\mathrm{Sr}^{2+} / \mathrm{Ca}^{2+}$ and ${ }^{44} \mathrm{Ca} /{ }^{40} \mathrm{Ca}$ fractionation during inorganic calcite formation: II. Ca isotopes: Geochimica et Cosmochimica Acta, v. 72, p. 3733-3745, doi:10.1016/j.gca.2008.05.033.

Tarduno, J.A., Sager, W.W., and Nogi, Y., 1995, 25. Early cretaceous magnetostratigraphy and paleolatitudes from the mid-pacific mountains: preliminary results bearing on guyot formation and pacific plate translation: in Proceedings of the Ocean Drilling Program, Scientific Results, v. 143, p. 3-14.

Lechler, M., Pogge von Strandmann, P.A.E., Jenkyns, H.C., Prosser, G., and Parente, M., 2015, Lithium-isotope evidence for enhanced silicate weathering during OAE 1a (Early Aptian Selli event): Earth and Planetary Science Letters, v. 432, p. 210-222, doi:10.1016/j.eps1.2015.09.052.

Wang, J., Jacobson, A.D., Zhang, H., Ramezani, J., Sageman, B.B., Hurtgen, M.T., Bowring, S.A., and Shen, S.-Z., 2019, Coupled $\delta^{44 / 40} \mathrm{Ca}, \delta^{88 / 86} \mathrm{Sr}$, and ${ }^{87} \mathrm{Sr} /{ }^{86} \mathrm{Sr}$ geochemistry across the end-Permian mass extinction event: Geochimica et Cosmochimica Acta, v. 262, p. 143165, doi:10.1016/j.gca.2019.07.035. 